\title{
Efficient synthesis of phenylene-ethynylene rods and their use as rigid spacers in divalent inhibitors
}

\author{
Francesca Pertici ${ }^{1}$, Norbert Varga ${ }^{2}$, Arnoud van Duijn ${ }^{1}$, Matias Rey-Carrizo ${ }^{1}$, \\ Anna Bernardi ${ }^{2}$ and Roland J. Pieters ${ }^{* 1}$
}

\section{Full Research Paper}

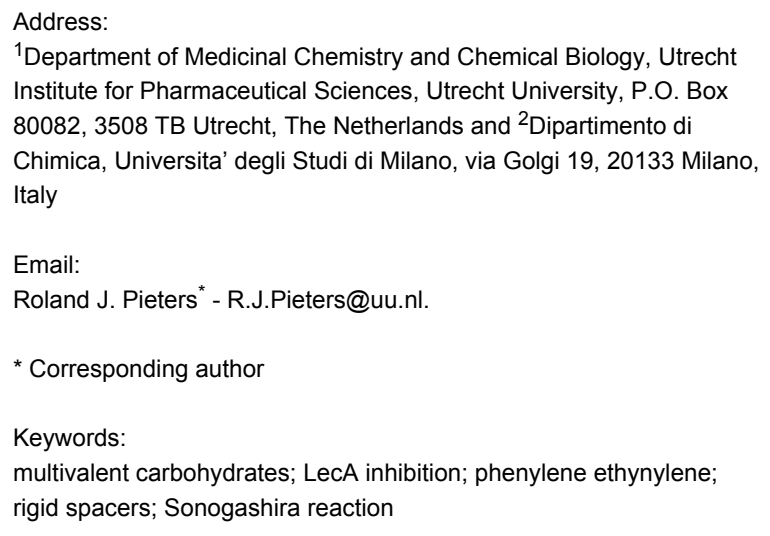

${ }^{1}$ Department of Medicinal Chemistry and Chemical Biology, Utrecht Institute for Pharmaceutical Sciences, Utrecht University, P.O. Box 80082, 3508 TB Utrecht, The Netherlands and 2Dipartimento di Chimica, Universita' degli Studi di Milano, via Golgi 19, 20133 Milano, Italy

Email:

Roland J. Pieters* - R.J.Pieters@uu.nl.

* Corresponding author

Keywords:

multivalent carbohydrates; LecA inhibition; phenylene ethynylene;

rigid spacers; Sonogashira reaction

Beilstein J. Org. Chem. 2013, 9, 215-222.

doi:10.3762/bjoc.9.25

Received: 06 December 2012

Accepted: 09 January 2013

Published: 31 January 2013

Associate Editor: S. Flitsch

(C) 2013 Pertici et al; licensee Beilstein-Institut.

License and terms: see end of document.

\begin{abstract}
The synthesis of phenylene-ethynylene rods and their use as rigid spacers is described. Alternation of a Sonogashira reaction and silyl group cleavage was used to obtain rigid spacers with even and odd numbers of phenylene units. Preliminary applications of these rods in divalent systems are shown. Inhibition studies with Pseudomonas Aeruginosa lectin LecA showed that the rigid spacer proved greatly beneficial for the inhibitory potency.
\end{abstract}

\section{Introduction}

Linker or spacer molecules have a wide range of applications in many areas of chemistry as bridging molecules between separate functional units. Spacers are often flexible but depending on the nature of the application, efforts have been made to make rigid linkages between functional units. Examples of these have been reported in areas such as nanoelectronics and nanooptics [1], surfactants [2-4], photoelectrochemical detection [5], catalysis [6], glycosylation reactions [7], and carbohydrate-protein interactions [8]. Many different strategies and molecule types have been used depending on the desired geometry, such as ring formation [9], carbohydrate-triazole conjugation [10], aryl-alkyne linked structures [11-15] and the use of DNA as a rigid bridge between silver nanoparticles and quantum dots [5]. Among the rigid linking units the phenylene-ethynylene unit has seen considerable interest in sensor [16] and molecularelectronics applications [17]. This is due to the specific fluorescent, conducting and electrochemical properties that the conjugated system confers to the molecule [18]. In the study of carbohydrate-protein interactions, it is now well known that making a system multivalent increases the binding or inhibitory 
potency of ligands, whose monovalent counterparts would otherwise be too weak to have biological relevance [19-22]. The spacer is an important factor in the design of an effective multivalent ligand [23]. While most systems reported thus far contain flexible spacers, there is a major untapped potential for systems based on rigid spacers, even though some flexibility may be needed to overcome design imperfections [10].

We herein describe the synthesis of rigid spacers of various lengths based on phenylene-ethynylene units and their incorporation into divalent ligands. For design purposes this system has the advantage that due to the high rigidity and linearity it is easy to predict their length, as was recently shown by EPR measurements [24]. The solubility of rigid hydrophobic spacers in an aqueous environment is notoriously poor, and therefore PEG attachments have been employed. Such PEG units were also incorporated in glycopolymers based on the phenylene-ethynylene repeating units by Seeberger and co-workers (see schematically in Figure 1a), who used them for the detection of bacteria [25]. The fluorescent properties of the polymer allowed a fast detection of the E. coli bacteria. Brewer et al. reported a divalent inhibitor with a short rigid spacer containing just a single phenylene-ethynylene [26]. The inhibition shown by this compound was disappointing since it was less potent than its flexible divalent counterpart. There are no other examples in the literature that show inhibition studies of lectins using divalent ligands directly connected by a rigid spacer based on phenylene-ethynylene units (Figure 1b).

a)

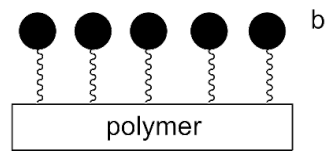

b)

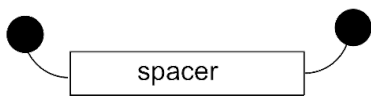

Figure 1: Schematic depiction of (a) a rigid phenylene-ethynylene polymer core with ligands attached via flexible chains, and (b) a divalent ligand using phenylene-ethynylene as a rigid spacer connecting the ligands.

In order to systematically study the effects of spacer lengths on the binding potencies of divalent ligands, having access to a series of spacers of well-defined lengths was imperative. We here report the synthesis of a series of spacers based on phenylene-ethynylene building blocks (Figure 2), with distinct syntheses for the compounds containing an even and an odd number of aromatic rings. One of the spacers was incorporated into the structure of a divalent galactoside ligand and was used to inhibit the virulence-linked lectin LecA of Pseudomonas aeruginosa [27,28].

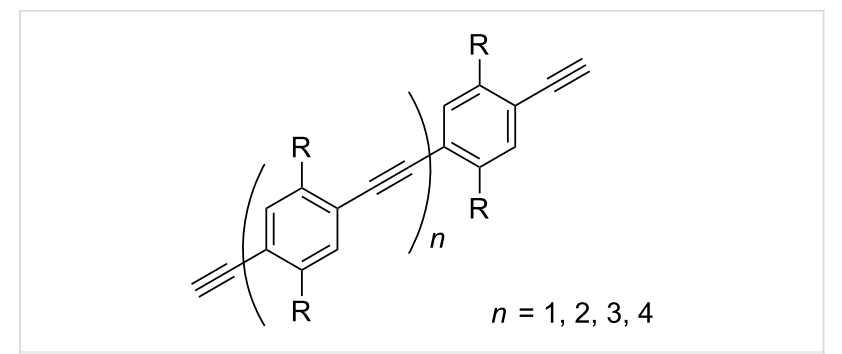

Figure 2: Generic structure of spacers containing an even $(n=1,3)$ and an odd $(n=2,4)$ number of units.

\section{Results and Discussion \\ Synthetic strategies}

Depending on the number of units in the spacer, two different routes can be applied. The pathway followed to obtain rods containing an even number of units is shown in Figure 3. The R group on the ring is used to increase the solubility of the system. The strategy relies on orthogonal protecting groups $\mathrm{R}^{1}$ and $\mathrm{R}^{2}$ of structure $\mathrm{A}$, to enable the selective deprotection needed to make B. Its free alkyne moiety can undergo a Sonogashira reaction with $\mathbf{C}$ to give $\mathbf{D}$. At this point the removal of the protecting group $\mathrm{R}^{1}$ and $\mathrm{R}^{2}$ can be performed, to either couple the ligands or elongate the system by a double Sonogashira reaction.

The strategy to prepare spacers containing an odd number of units is shown in Figure 4. The strategy is more straightforward since it does not require any orthogonal deprotection step. Starting with $\mathbf{F}$, a double Sonogashira reaction with $\mathbf{C}$ should yield the three-unit system $\mathbf{G}$. Removal of the protecting groups $\mathrm{R}^{1}$ can be performed, to either couple the ligands or elongate the system by a double Sonogashira reaction.

\section{Synthesis of the building blocks}

The building blocks were prepared as shown in Scheme 1. In the general structures shown in Figure 3 and Figure 4 the R group is used to increase the solubility. For this purpose diethylene glycol was used as a side chain, which terminated as a free hydroxy group for $\mathbf{1}$ and a methoxy group for $\mathbf{2}$. Silyl groups were used as selective protective groups for the alkyne moiety. Monoalkyne 3 and bisalkyne 4 were made from 1 [29] by a Sonogashira reaction with TIPS-acetylene in $31 \%$ and $50 \%$, respectively. Similarly, 5 and $\mathbf{6}$ were obtained from $\mathbf{2}$, in agreement with a recent literature report [16]. The use of the microwave reactor allowed a shorter reaction time $(20 \mathrm{~min}$ at $\left.60{ }^{\circ} \mathrm{C}\right)$ than the one reported in the literature $\left(24 \mathrm{~h}\right.$ at $40{ }^{\circ} \mathrm{C}$ for 6 and $24 \mathrm{~h}$ at $10^{\circ} \mathrm{C}$ for $\mathbf{5}$ ).

\section{Synthesis of a two-unit spacer}

The strategy of Figure 3 was applied to the synthesis of the twounit spacer. In order to obtain our orthogonally protected inter- 
<smiles>[R]C#Cc1cc([R])c(C#C)cc1[R]</smiles>

A

B

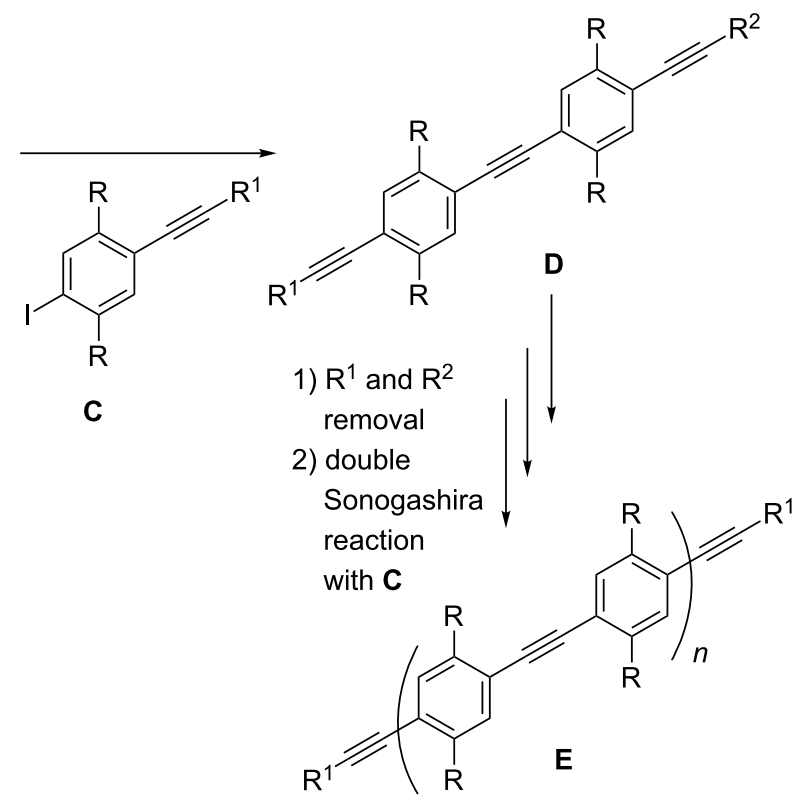

Figure 3: Synthetic strategy for rigid spacers with an even number of units.

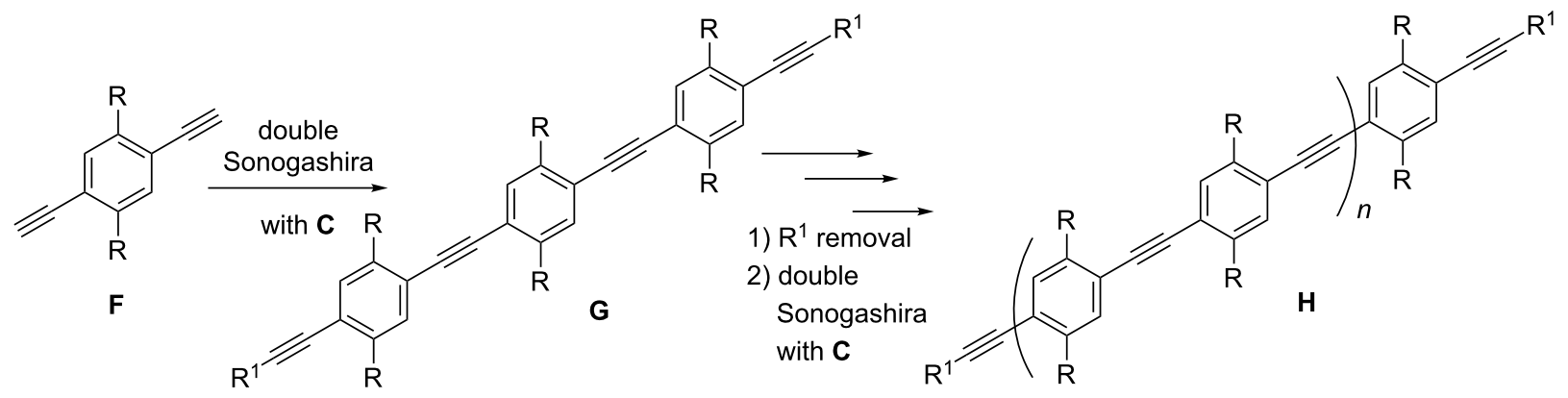

Figure 4: Synthetic strategy for rigid spacers with an odd number of units.<smiles>[R]Oc1cc(I)c(O[R])cc1I</smiles><smiles>[R]C#Cc1cc(O[R2])c(I)cc1O[R]</smiles><smiles>[R]C#Cc1cc(O[R])c(C#[R])cc1O[R7]</smiles>

$\mathrm{R}^{1}=\mathrm{TIPS}$ or $\mathrm{TMS}$

$$
\text { 2: } \mathrm{R}=\text { = }
$$$$
\text { 3: } \mathrm{R}=\text { 终 } \mathrm{O} \sim \mathrm{OH}
$$$$
R^{1}=\text { TIPS }
$$$$
\text { 5: } \mathrm{R}=\text { 令 }
$$$$
R^{1}=T M S
$$
4: $\mathrm{R}=\xi \bumpeq \mathrm{O} ح \mathrm{OH}$$$
\mathrm{R}^{1}=\mathrm{TIPS}
$$$$
\text { 6: } \mathrm{R}=\text { 令 }
$$$$
R^{1}=T M S
$$ 
mediate 7, mono-iodo compound 5 was coupled with tertbutyl(ethynyl)dimethylsilane (TBDMS-acetylene, Scheme 2). From 7 the more labile TMS group was removed by using $\mathrm{K}_{2} \mathrm{CO}_{3}$ to give 8 . This compound was coupled to 5 by a Sonogashira reaction to give the protected two-unit spacer $\mathbf{9}$. Removal of its silyl protecting groups with TBAF yielded the desired two-unit spacer 10. A slightly different strategy (see Supporting Information, Scheme S1) was used starting from the mono-iodo derivative 3 , because partial silyl migration to the free hydroxy groups was observed while attempting mono-desilylation.

\section{Synthesis of three-unit spacers}

To obtain the three-unit spacer, the odd strategy (Figure 4) was applied starting with compound $\mathbf{F}$. In order to make $\mathbf{F}$, the silyl protecting groups of both $\mathbf{4}$ and $\mathbf{6}$ were removed (Scheme 3).<smiles>[R]C#Cc1cc([R]Oc2cc(C#C[R])c(O[R])cc2C#Cc2cc(O[R])c(C#C[R])cc2O[R])c(C#C[R])cc1[R]</smiles>

Scheme 2: Synthesis of a two-unit spacer. (a) $\mathrm{PdCl}_{2}\left(\mathrm{PPh}_{3}\right)_{2}$, Cul, TEA, THF, microwave, $60{ }^{\circ} \mathrm{C}, 20 \mathrm{~min}, 81 \%$ for $7,79 \%$ for 9 ; (b) $\mathrm{K}_{2} \mathrm{CO}_{3}, \mathrm{MeOH}^{2}$ $\mathrm{CH}_{2} \mathrm{Cl}_{2}, 45 \mathrm{~min}, 78 \%$; (c) TBAF, THF, $84 \%$.<smiles>[R]C#Cc1cc(O[R])c(C#Cc2cc(O[R])c(C#Cc3cc(O[R])c(C#C[R])cc3[R])cc2O)cc1[R]</smiles> 
For 4 the TIPS groups were removed with an excess of TBAF to give 11. Compound $\mathbf{6}$, which bears the TMS group, was treated with $\mathrm{K}_{2} \mathrm{CO}_{3}$ to afford 12. Both 11 and 12 were elongated in a double Sonogashira reaction with $\mathbf{3}$ and $\mathbf{5}$, respectively. Of the products, 14 was deprotected by using $\mathrm{K}_{2} \mathrm{CO}_{3}$ to yield the three-unit spacer $\mathbf{1 5}$, according to a recent literature report [16].

\section{Synthesis of a four-unit spacer}

The four-unit spacer was synthesized starting from the twounit spacer $\mathbf{1 0}$ and the iodo compound $\mathbf{5}$ through a double Sonogashira reaction to give $\mathbf{1 6}$ (Scheme 4). Deprotection of the two alkyne moieties with $\mathrm{K}_{2} \mathrm{CO}_{3}$ afforded the four-unit spacer 17.

\section{Synthesis of a five-unit spacer}

The synthesis of the five-unit spacer started with the elongation of the three-unit spacer $\mathbf{1 5}$ through a double Sonogashira reaction with iodo compound $\mathbf{5}$ to give $\mathbf{1 8}$ (Scheme 5). The five-unit spacer 19 was obtained after deprotection of the alkyne moieties with $\mathrm{K}_{2} \mathrm{CO}_{3}$.

\section{Preliminary application}

As part of our program on bacterial adhesion inhibition by multivalent carbohydrates, the bacterial lectin LecA, a virulence factor of the problematic pathogen Pseudomonas aeruginosa is a target of interest [30,31]. This tetrameric lectin binds galactosides and the shortest distance between two binding sites is around $26 \AA[20,28]$. We previously noted that the use of a rigid spacer with some flexibility in the aglycon chain connecting the galactose ligands, led to more potent inhibition [10]. Since the distance to cover is ca. $26 \AA$, the best match in the phenylene-ethynylene series is the three-unit spacer $\mathbf{1 5}$. Just the spacer, without the aglycon linking moiety measures around $22 \AA$. Coupling of the galactose ligand and the flexible aglycon part should result in a promising compound. CuAAC of $\mathbf{1 5}$ with the ligand 20 was performed as shown in Scheme 6 to give 21. The acetyl protecting groups were removed by using $\mathrm{NaOMe}$ in $\mathrm{MeOH}$, yielding final product $\mathbf{2 2}$.

Compound 13, bearing hydroxy-terminated diethylene glycol chains, has the potential of solubilizing in water constructs bearing active spearheads less hydrophilic than simple sugars.

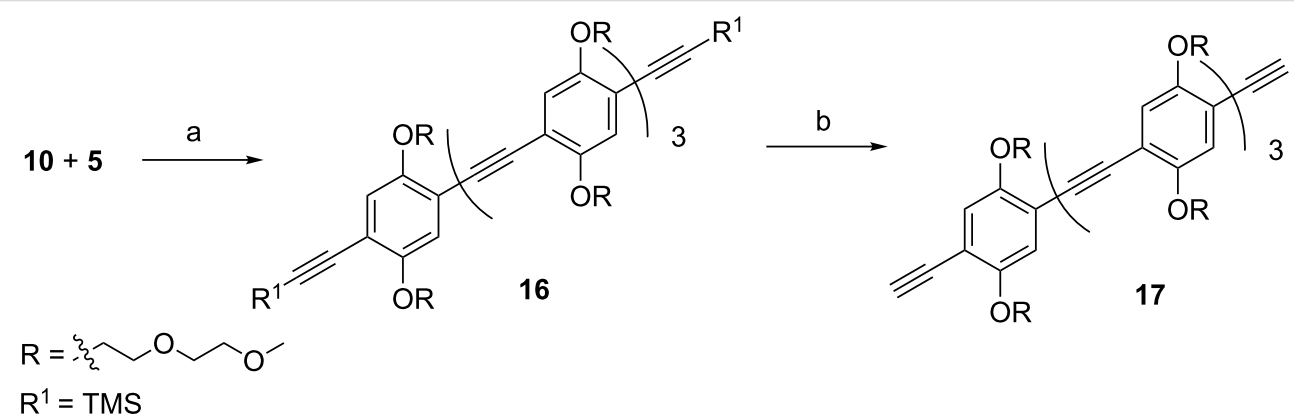

Scheme 4: Synthesis of a four-unit spacer. (a) $\mathrm{PdCl}_{2}\left(\mathrm{PPh}_{3}\right)_{2}$, Cul, TEA, THF, microwave, $60{ }^{\circ} \mathrm{C}, 20 \mathrm{~min}, 73 \%$; (b) $\mathrm{K}_{2} \mathrm{CO}_{3}, \mathrm{MeOH} \mathrm{CH}_{2} \mathrm{Cl}_{2}, 45 \mathrm{~min}$, $76 \%$.

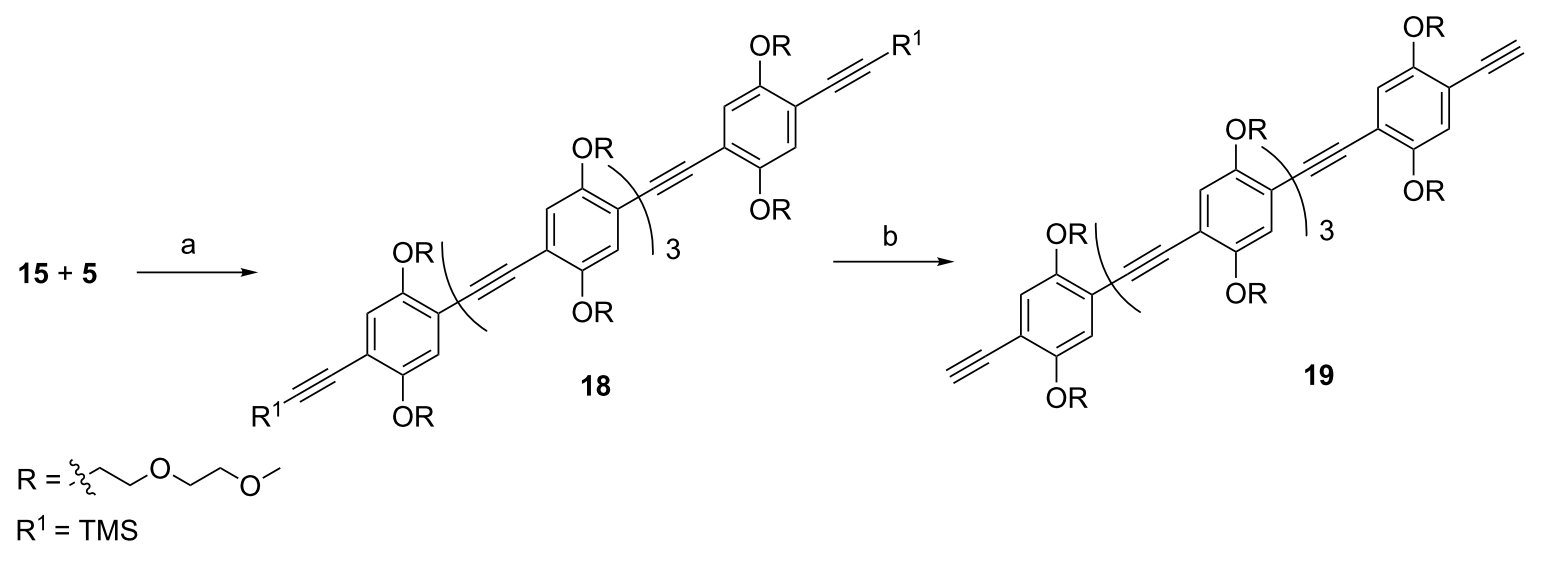




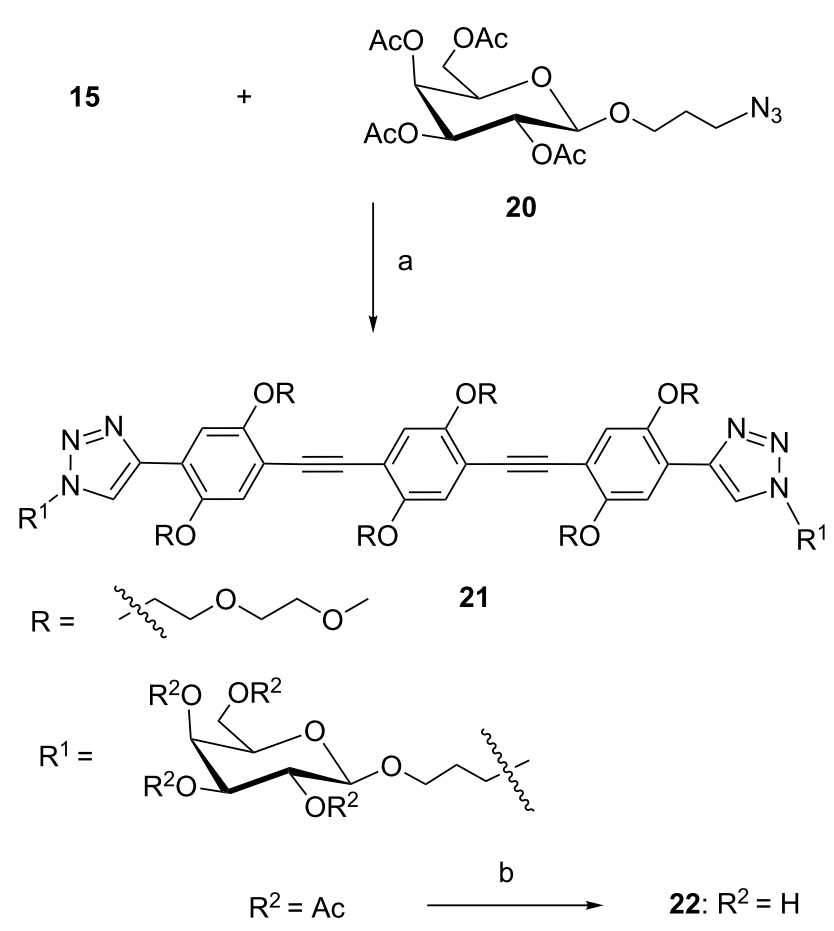

Scheme 6: Synthesis of divalent ligand 22. (a) $\mathrm{CuSO}_{4} \cdot 5 \mathrm{H}_{2} \mathrm{O}, \mathrm{Na}$-ascorbate, $\mathrm{DMF} / \mathrm{H}_{2} \mathrm{O}$, microwave, $80{ }^{\circ} \mathrm{C}, 40 \mathrm{~min}, 85 \%$; (b) $\mathrm{NaOMe}, \mathrm{MeOH}, 41 \%$.

We have been developing pseudo-disaccharide molecules such as 23 [32] (Scheme 7) as mimics of mannose disaccharides for the interaction with DC-SIGN and other C-lectins [33-35]. This molecule and its derivatives [36] contain lipophilic moieties that generally increase their affinity for the target proteins, but can create solubility problems. Desilylation of $\mathbf{1 3}$ (TBAF, THF, Scheme 7) followed by in situ CuAAC with the pseudo-disaccharide $\mathbf{2 3}$ led to the divalent ligand $\mathbf{2 4}$, which was found to be fully soluble in water, at least up to millimolar concentrations. Compound $\mathbf{2 4}$ is a mimic for DC-SIGN inhibition and its bioactivity will be tested elsewhere.

\section{Inhibition studies}

The inhibitory potency of $\mathbf{2 2}$ for LecA was studied in an ELISA type assay by using a glycochip as the solid phase [10]. In this assay an $\mathrm{IC}_{50}$ value of $0.9 \mu \mathrm{M}$ was determined (Table 1). This compared favorably with the monovalent reference compound 25 (Figure 5), which exhibited an $\mathrm{IC}_{50}$ of $120 \mu \mathrm{M}$ [10]. Similarly, the divalent compound $\mathbf{2 2}$ was a more potent inhibitor than the higher valency compound 26, especially when expressed as the relative potency per sugar, which is 11 for the tetravalent $\mathbf{2 6}[37,38]$ and 67 for $\mathbf{2 2}$.

\section{Conclusion}

In this work a strategy for the synthesis of rigid spacers or rods of different length based on phenylene-ethynylene units was developed. On the phenyl ring, two versions of a solubilizing

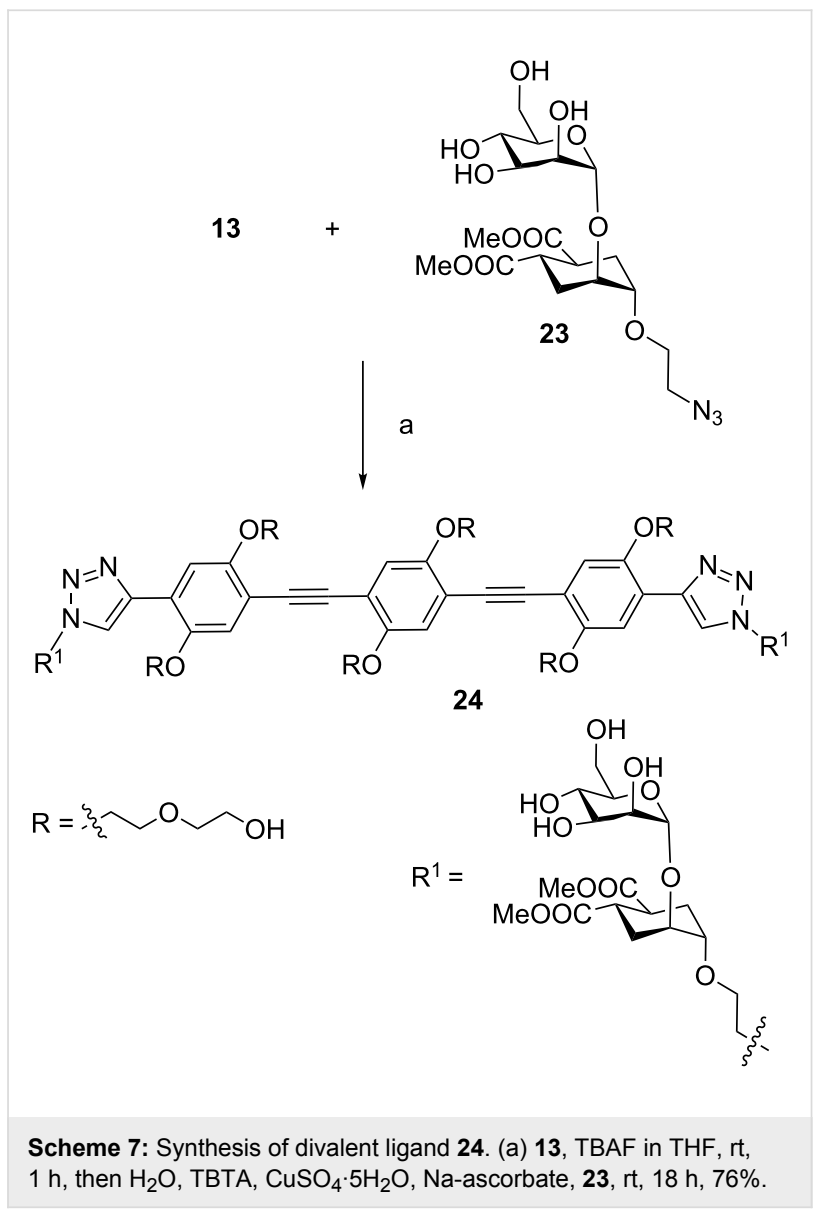


Table 1: Inhibitory potency of mono, di- and tetravalent galactosides on LecA binding ${ }^{a}$

\begin{tabular}{llll} 
Compound & Valency & $\mathrm{IC}_{50} / \mu \mathrm{M}$ & $\begin{array}{l}\text { Relative } \\
\text { Potency } \\
\text { (per sugar) }\end{array}$ \\
\hline 25 & 1 & 120 & 1 \\
26 & 4 & 2.7 & $44(11)$ \\
22 & 2 & 0.90 & $133(67)$ \\
\hline
\end{tabular}

aFITC-labeled LecA, $20 \mu \mathrm{g} \mathrm{mL}^{-1}$ binding to a galactoside functionalized surface.

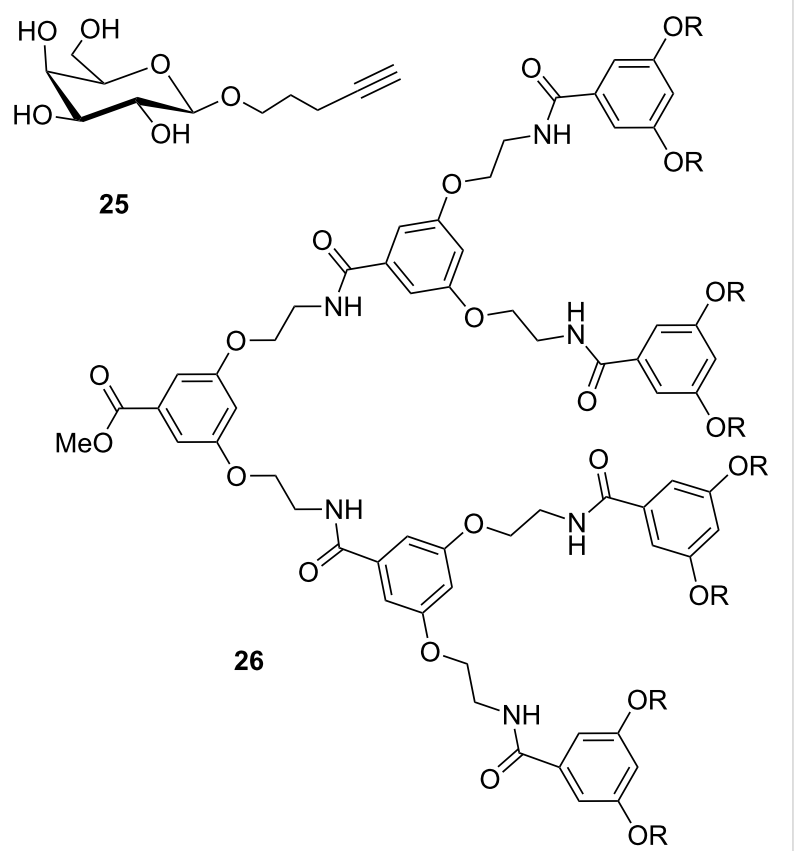

$R=$<smiles>CCc1cn(CCCOC2(O)OC(CO)C(O)C(O)C(C)C2O)nn1</smiles>

Figure 5: Previously tested compounds.

diethylene glycol moiety were used, one terminating in a hydroxy and one terminating in a methoxy group. The hydroxy version led to some migration of the silyl protecting group upon attempted monodeprotection, and alternative strategies had to be devised for the synthesis of the two-unit spacer. Compounds 17 and 19, containing four and five phenylene-ethynylene units, respectively, can still be further elongated, depending on the need of the project, thus enabling the preparation of long spacers with a well-defined number of monomeric units. The $\mathrm{CuAAC}$ of the three unit spacer 15 with a galactose ligand gave the divalent ligand 21 in good yield. After deprotection this compound was used to inhibit the lectin LecA from Pseudomonas aeruginosa. A major potency increase was seen with the divalent structure based on the phenylene-ethynylene spacer, with an $\mathrm{IC}_{50}$ of $0.9 \mu \mathrm{M}$, i.e., a 133 -fold potency increase over a monovalent reference compound, clearly showing the potential for spacers of this nature.

It was also shown that the three-unit spacer $\mathbf{1 3}$ could be used in a one-pot desilylation and $\mathrm{CuAAC}$ reaction to give $\mathbf{2 4}$, which was found to be fully soluble in water, despite the more lipophilic nature of the active ligand. This finding paves the way for the synthesis and evaluation of polyvalent glycomimetics with regularly spaced cores to be used for Manspecific C-lectin inhibition assays. With access to structural data of target lectins, the design of multivalent inhibitors can be performed on a customized level, where the selection of the proper spacer is based on the information about the binding site, such as its density, orientation and position. Furthermore, the rigidity of the rods described above can contribute to overcoming the entropic penalty of flexible multivalent scaffolds, thus improving the overall activity of the ligands.

\section{Supporting Information}

\section{Supporting Information File 1}

Synthetic procedures and spectral data.

[http://www.beilstein-journals.org/bjoc/content/

supplementary/1860-5397-9-25-S1.pdf]

\section{Acknowledgements}

This research is supported by the Dutch Technology Foundation STW, applied science division of NWO and the Technology Program of the Ministry of Economic Affairs. N.V. was supported by a European fellowship under the ITN project Carmusys (FP7-MC-ITN-213592). We thank the COST Action CM1102 Multiglyconano for support and Stefania Ordanini for optimization of the synthesis of $\mathbf{3 0}$ (see Supporting Information File 1, Scheme S1). M.R.C. acknowledges Fundació Crèdit Andorrà for a masters grant.

\section{References}

1. Rahman, A. F. M. M.; Wang, F.; Matsuda, K.; Kimura, T.; Komatsu, N. Chem. Sci. 2011, 2, 862-867. doi:10.1039/c0sc00635a

2. Zhu, D.-Y.; Cheng, F.; Chen, Y.; Jiang, S.-C. Colloids Surf., A 2012, 397, 1-7. doi:10.1016/j.colsurfa.2012.01.006

3. Zhu, S.; Liu, L.; Cheng, F. J. Surfactants Deterg. 2011, 14, 221-225. doi:10.1007/s11743-010-1226-3

4. Mivehi, L.; Bordes, R.; Holmberg, K. Langmuir 2011, 27, 7549-7557. doi:10.1021/la200539a

5. Zhao, W.-W.; Yu, P.-P.; Shan, Y.; Wang, J.; Xu, J.-J.; Chen, H.-Y. Anal. Chem. 2012, 84, 5892-5897. doi:10.1021/ac300127s

6. Framery, E.; Andrioletti, B.; Lemaire, M. Tetrahedron: Asymmetry 2010, 21, 1110-1124. doi:10.1016/j.tetasy.2010.04.028 
7. Tiwari, V. K.; Kumar, A.; Richard, R.; Schmidt, R. R. Eur. J. Org. Chem. 2012, 2945-2956. doi:10.1002/ejoc.201101815

8. Deniaud, D.; Julienne, K.; Gouin, S. G. Org. Biomol. Chem. 2011, 9, 966-979. doi:10.1039/c0ob00389a

9. Leyden, R.; Velasco-Torrijos, T.; André, S.; Gouin, S.; Gabius, H.-J.; Murphy, P. V. J. Org. Chem. 2009, 74, 9010-9026. doi:10.1021/jo901667r

10. Pertici, F.; Pieters, R. J. Chem. Commun. 2012, 48, 4008-4010. doi:10.1039/c2cc30234a

11. Martos-Maldonado, M. C.; Quesada-Soriano, I.; Casas-Solvas, J. M.; García-Fuentes, L.; Vargas-Berenguel, A. Eur. J. Org. Chem. 2012, 2560-2571. doi:10.1002/ejoc.201101598

12. Lieffrig, J.; Yamamoto, H. M.; Kusamoto, T.; Cui, H.; Jeannin, O.; Fourmigué, M.; Kato, R. Cryst. Growth Des. 2011, 11, 4267-4271. doi:10.1021/cg200843w

13. Ramachandra, S.; Schuermann, K. C.; Edafe, F.; Belser, P.; Nijhuis, C. A.; Reus, W. F.; Whitesides, G. M.; De Cola, L. Inorg. Chem. 2011, 50, 1581-1591. doi:10.1021/ic1002868

14. Touaibia, M.; Roy, R. J. Org. Chem. 2008, 73, 9292-9302. doi:10.1021/jo801850f

15. Bergeron-Brlek, M.; Giguère, D.; Shiao, T. C.; Saucier, C.; Roy, R. J. Org. Chem. 2012, 77, 2971-2977. doi:10.1021/jo2025652

16. Wu, Y.; Dong, Y.; Li, J.; Huang, X.; Cheng, Y.; Zhu, C. Chem.-Asian J. 2011, 6, 2725-2729. doi:10.1002/asia.201100534

17. Kaliginedi, V.; Moreno-García, P.; Valkenier, H.; Hong, W.; García-Suárez, V. M.; Buiter, P.; Otten, J. L. H.; Hummelen, J. C.; Lambert, C. J.; Wandlowski, T. J. Am. Chem. Soc. 2012, 134, 5262-5275. doi:10.1021/ja211555x

18. Pinto, M. R.; Schanze, K. S. Synthesis 2002, 1293-1309. doi:10.1055/s-2002-32541

19. Fan, E.; Zhang, Z.; Minke, W. E.; Hou, Z.; Verlinde, C. L. M. J.; Hol, W. G. J. J. Am. Chem. Soc. 2000, 122, 2663-2664. doi:10.1021/ja993388a

20. Kitov, P. I.; Sadowska, J. M.; Mulvey, G.; Armstrong, G. D.; Ling, H.; Pannu, N. S.; Read, R. J.; Bundle, D. R. Nature 2000, 403, 669-672. doi:10.1038/35001095

21. Branderhorst, H. M.; Liskamp, R. M. J.; Visser, G. M.; Pieters, R. J. Chem. Commun. 2007, 5043-5045. doi:10.1039/b711070g

22. Schwefel, D.; Maierhofer, C.; Beck, J. G.; Seeberger, S.; Diederichs, K.; Möller, H. M.; Welte, W.; Wittmann, V. J. Am. Chem. Soc. 2010, 132, 8704-8719. doi:10.1021/ja101646k

23. Braun, P.; Nägele, B.; Wittmann, V.; Drescher, M. Angew. Chem., Int. Ed. 2011, 50, 8428-8431. doi:10.1002/anie.201101074

24. Jeschke, G.; Sajid, M.; Schulte, M.; Ramezanian, N.; Volkov, A.; Zimmermann, H.; Godt, A. J. Am. Chem. Soc. 2010, 132, 10107-10117. doi:10.1021/ja102983b

25. Disney, M. D.; Zheng, J.; Swager, T. M.; Seeberger, P. H. J. Am. Chem. Soc. 2004, 126, 13343-13346. doi:10.1021/ja047936i

26. Dam, T. K.; Oscarson, S.; Roy, R.; Das, S. K.; Pagé, D.; Macaluso, F.; Brewer, C. F. J. Biol. Chem. 2005, 280, 8640-8646. doi:10.1074/jbc.M412827200

27. Imberty, A.; Wimmerová, M.; Mitchell, E. P.; Gilboa-Garber, N. Microbes Infect. 2004, 6, 221-228. doi:10.1016/j.micinf.2003.10.016

28. Cioci, G.; Mitchell, E. P.; Gautier, C.; Wimmerová, M.; Sudakevitz, D.; Pérez, S.; Gilboa-Garber, N.; Imberty, A. FEBS Lett. 2003, 555, 297-301. doi:10.1016/S0014-5793(03)01249-3

29. Zhou, Q.; Swager, T. M. J. Am. Chem. Soc. 1995, 117, 12593-12602. doi:10.1021/ja00155a023
30. Pieters, R. J. Med. Res. Rev. 2007, 27, 796-816. doi:10.1002/med.20089

31. Pieters, R. J. Adv. Exp. Med. Biol. 2011, 715, 227-240. doi:10.1007/978-94-007-0940-9_14

32. Mari, S.; Posteri, H.; Marcou, G.; Potenza, D.; Micheli, F.; Cañada, F. J.; Jiménez-Barbero, J.; Bernardi, A. Eur. J. Org. Chem. 2004, 5119-5125. doi:10.1002/ejoc.200400520

33. Reina, J. J.; Sattin, S.; Invernizzi, D.; Mari, S.; Martínez-Prats, L.; Tabarani, G.; Fieschi, F.; Delgado, R.; Nieto, P. M.; Rojo, J.; Bernardi, A. ChemMedChem 2007, 2, 1030-1036. doi:10.1002/cmdc.200700047

34. Luczkowiak, J.; Sattin, S.; Sutkevičiūtè, I.; Reina, J. J.; Sánchez-Navarro, M.; Thépaut, M.; Martínez-Prats, L.; Daghetti, A.; Fieschi, F.; Delgado, R.; Bernardi, A.; Rojo, J. Bioconjugate Chem. 2011, 22, 1354-1365. doi:10.1021/bc2000403

35. Orsini, F.; Villa, P.; Parrella, S.; Zangari, R.; Zanier, E. R.; Gesuete, R.; Stravalaci, M.; Fumagalli, S.; Ottria, R.; Reina, J. J.; Paladini, A.; Micotti, E.; Ribeiro-Viana, R.; Rojo, J.; Pavlov, V. I.; Stahl, G. L.; Bernardi, A.; Gobbi, M.; De Simoni, M.-G. Circulation 2012, 126 , 1484-1494. doi:10.1161/CIRCULATIONAHA.112.103051

36. Obermajer, N.; Sattin, S.; Colombo, C.; Bruno, M.; Švajger, U.; Anderluh, M.; Bernardi, A. Mol. Diversity 2011, 15, 347-360. doi:10.1007/s11030-010-9285-y

37. Parera Pera, N.; Branderhost, H. M.; Kooij, R.; Maierhofer, C.; van der Kaanden, M.; Liskamp, R. M. J.; Wittman, V.; Ruijtenbeek, R.; Pieters, R. J. ChemBioChem 2010, 11, 1896-1904. doi:10.1002/cbic. 201000340

38. Branderhorst, H. M.; Ruijtenbeek, R.; Liskamp, R. M. J.; Pieters, R. J. ChemBioChem 2008, 9, 1836-1844. doi:10.1002/cbic.200800195

\section{License and Terms}

This is an Open Access article under the terms of the Creative Commons Attribution License (http://creativecommons.org/licenses/by/2.0), which permits unrestricted use, distribution, and reproduction in any medium, provided the original work is properly cited.

The license is subject to the Beilstein Journal of Organic Chemistry terms and conditions:

(http://www.beilstein-journals.org/bjoc)

The definitive version of this article is the electronic one which can be found at: doi:10.3762/bjoc. 9.25 